\title{
Thermocrispum gen. nov., a New Genus of the Order Actinomycetales, and Description of Thermocrispum municipale sp. nov. and Thermocrispum agreste sp. nov.
}

\author{
F. KORN-WENDISCH, ${ }^{1 *}$ F. RAINEY, ${ }^{2}$ R. M. KROPPENSTEDT, ${ }^{2}$ A. KEMPF, ${ }^{1}$ A. MAJAZZA, ${ }^{3}$ H. J. KUTZNER, ${ }^{1}$ \\ AND E. STACKEBRANDT ${ }^{2}$ \\ Institut für Mikrobiologie der Technischen Hochschule Darmstadt, D-64287 Darmstadt, ${ }^{1}$ Deutsche Sammlung von \\ Mikroorganismen und Zellkulturen GmbH, D-38124 Braunschweig, ${ }^{2}$ and Institut für Experimentalphysik II der \\ Technischen Hochschule Darmstadt, D-64289 Darmstadt, ${ }^{3}$ Germany
}

\begin{abstract}
Ten strains of thermophilic actinomycetes were isolated from waste and mushroom composts, as well as from the air of compost plants and a refuse incineration plant in Germany. These organisms produce white aerial mycelia and form hyphae with so-called pseudosporangia that fragment into rod-like structures. The organisms have type III cell walls (meso-diaminopimelic acid and whole-cell sugar type C), the phospholipid type is type PII, and mycolic acids are not present. The major menaquinone is $\mathrm{MK}-9\left(\mathrm{H}_{4}\right)$, and the fatty acids are mainly iso- and anteiso-branched fatty acids, hydroxy fatty acids, and 10-methyl-branched fatty acids. The guanine-plus-cytosine content of the DNA is 69 to 73 mol\%. The chemotaxonomic markers (especially whole-cell sugar type $C$ ) and $16 \mathrm{~S}$ ribosomal DNA sequence data indicated that these organisms represent a new genus of the order Actinomycetales, for which the name Thermocrispum is proposed. On the basis of phylogenetic and phenotypic data, this new genus is closely related to members of the family Pseudonocardiaceae and related taxa and contains two species: Thermocrispum municipale sp. nov. and Thermocrispum agreste sp. nov. The type species of the genus is $T$. municipale, with type strain MKD 35 (= DSM 44069), and the type strain of $T$. agreste is CHB 77 (= DSM 44070).
\end{abstract}

Thermophilic actinomycetes play an important role in habitats where decomposition of organic matter takes place at elevated temperatures and under aerobic and microaerobic conditions (e.g., improperly stored hay, cereal grains, manure, straw, and various composts, including mushroom compost and municipal waste compost). This fact is relevant for the process engineering now used to compost and recycle organic material from plant biomass, domestic garbage, and other urban wastes. Some members of the thermophilic actinomycetes are known to cause an allergic lung disease (extrinsic allergic alveolitis [farmer's lung] [33]) that results from inhalation of spores of these organisms when they are liberated at high concentrations $\left(10^{6}\right.$ to $10^{10} \mathrm{CFU} / \mathrm{m}^{3}$ of air). This disease is related to agricultural practices, including production of compost for mushroom growing (mushroom compost $[12,63]$ ) and composting techniques (waste treatment) (i.e., parameters that determine mass development and methods used to prevent outbreaks of disease). Finally, thermophilic actinomycetes are involved in the deterioration of natural and industrial products (37), and some of these organisms produce exoenzymes and bioactive compounds of biotechnological interest.

During our investigation of the ecology of thermophilic actinomycetes, we isolated 10 novel strains from municipal waste compost and mushroom compost, as well as from the air of compost plants and an incineration plant in southern Germany. Macroscopically, these isolates were similar to members of the genus Saccharopolyspora, a genus belonging to the family Pseudonocardiaceae, and their chemotaxonomic markers (except their cell wall type) were the same as the chemotaxonomic markers of members of this family. At the present time, the family Pseudonocardiaceae encompasses the genera

\footnotetext{
* Corresponding author. Mailing address: Institut für Mikrobiologie der Technischen Hochschule Darmstadt, Schnittspahnstr. 9, D-64287 Darmstadt, Germany. Phone: 49615116 5449. Fax: 496151164808.
}

Actinopolyspora, Amycolatopsis, Kibdelosporangium, Pseudonocardia, Saccharomonospora, and Saccharopolyspora (11). The genera Amycolata and Pseudonocardia were recently combined in an emended genus Pseudonocardia (64). On the basis of the results of reverse transcriptase sequencing of 16S rRNA, Bowen et al. (4) suggested that the genus Saccharothrix, a genus with wall chemotype III according to Lechevalier and Lechevalier (41) but with galactose and rhamnose as characteristic sugars, should also be classified in the family Pseudonocardiaceae. Recently, Warwick et al. (64) investigated the relationships between this family and the genera Actinokineospora (a chemotype IV genus described by Hasegawa [18]) and Saccharothrix by using 16 S rRNA sequencing. The results of these authors confirmed the close relationship of these taxa but did not unequivocally support transfer of the genera Actinokineospora and Saccharothrix to the family Pseudonocardiaceae.

In this study, we determined the taxonomic status and affinities of our 10 new isolates by using macroscopic, physiological, and biochemical criteria, as well as phage typing and $16 \mathrm{~S}$ rRNA sequencing, and compared these organisms with reference strains belonging to all genera of the family Pseudonocardiaceae and reference strains belonging to the genera Actinokineospora, Kutzneria, and Saccharothrix, as well as some other type III cell wall actinomycetes.

\section{MATERIALS AND METHODS}

Isolation of organisms. The 10 strains which we studied were isolated in the course of screening for thermophilic actinomycetes in different biotopes in 1990 through 1992. Six strains (MKD8, MKD10, MKD19, MKD35 ${ }^{\mathrm{T}}$ [T = type strain], MKD38, and MKD57) were isolated from municipal waste compost produced by a compost plant in the south of Germany, two strains (TMK2 and TMD78) were isolated from the air of two different compost plants, one strain (TMS14) was isolated from the air of a refuse incineration plant, and one strain $\left(\mathrm{CHB} 77^{\mathrm{T}}\right)$ was isolated from mushroom compost used by a mushroom cultivator in Beerfelden, Germany.

Two isolation methods were used: (i) the dilution plate technique was used to isolate organisms from different habitats, and (ii) an Andersen sampler was used 
to collect isolates from aerosols at waste-composting plants. A temperature of $50^{\circ} \mathrm{C}$ was used for isolation, and a total of 21 media (peptone-maize agar [PM agar], R8 agar [1], and Trypticase soy agar [TSA] were used as the basal media) supplemented with various antibiotics and dyes (separately or in combination) were used to selectively isolate thermophilic actinomycetes. To inhibit fungal growth, cycloheximide and nystatin $(50 \mu \mathrm{g} / \mathrm{ml}$ each $)$ were added to all media. The new strains were found to grow on the following six media: R8 agar and TSA (control media without antibiotics), TSA supplemented with rifampin (10 $\mu \mathrm{g} / \mathrm{ml})$, TSA supplemented with erythromycin and oleandomycin $(100 \mu \mathrm{g} / \mathrm{ml}$ each), TSA supplemented with novobiocin $(25 \mu \mathrm{g} / \mathrm{ml})$, and PM agar supplemented with novobiocin $(25 \mu \mathrm{g} / \mathrm{ml})$.

Reference organisms. The following type strains of mesophilic and thermophilic actinomycetes were used in comparative studies: Actinokineospora riparia IFO 14541, Actinomadura madurae CCM 136 (= DSM 43067), Actinopolyspora halophila ATCC 27976 (= DSM 43834), Amycolatopsis azurea NRRL 11412 (= DSM 43854), Amycolatopsis fastidiosa ATCC 31181 (= DSM 43855), Amycola topsis mediterranei DSM 40501, Amycolatopsis methanolica NCIB 11946, Kibdelosporangium aridum ATCC 39323 (= DSM 43828), Kutzneria viridogrisea DSM 43850, Microtetraspora glauca ATCC 23057 (= DSM 43311), Nocardiopsis dassonvillei ATCC 23218 (= DSM 43111), Pseudonocardia autotrophica DSM 43210, Pseudonocardia thermophila ATCC 19285 (= DSM 43832), Saccharothrix australiensis ATCC 31947 (= DSM 43800), Saccharomonospora viridis ATCC 15386 (= DSM 43754), Saccharopolyspora erythraea NRRL 2338 (= DSM 40517), Saccharopolyspora hirsuta DSM 43463, Saccharopolyspora hordei NCIB 12824 (= DSM 44065), Saccharopolyspora rectivirgula ATCC 33515 (= DSM 43747), Thermomonospora curvata ATCC 19995 (= DSM 43183), and Nocardioides simplex DSM 20130. In addition, two unpublished sequences, the 16S rRNA sequences of "Pseudonocardia nitrificans" IFAM 379 and "Pseudonocardia petroleophila" IFAM 78, were included in the sequence analysis.

Cultural characteristics. The following media were used for general cultivation and morphological characterization: glucose-yeast extract-malt extract agar (GYM agar) (26) and TSA (16), each prepared with and without $5 \% \mathrm{NaCl}$; Czapek-Dox yeast extract-casein agar (CYC agar) (7); glycerol-arginine agar (10); Hickey-Tresner agar; PM agar (16); oatmeal agar (58) supplemented with trace element solution SPV-4 (26); potato-carrot agar (8); R2A agar (52); and R8 agar (1).

Morphology. Light microscopy was performed as described by Greiner-Mai et al. (16). For transmission electron microscopy, Formvar-coated grids were gently pressed on the surface of a preparation containing sporulating colonies and were then viewed with a Zeiss model EM-109 transmission electron microscope at magnifications of $\times 7,000$ and $\times 12,000$. For scanning electron microscopy, suitable agar blocks containing well-sporulated colonies were cut out with a scalpel, mounted on aluminum stubs with colloidal silver paste, and freeze dried. The probes were then sputter coated with gold under a vacuum (Hummer I apparatus; Technics, Inc.) and examined at magnifications of $\times 2,500$ to $\times 20,000$ with a Philips model SEM 505 scanning electron microscope.

Physiological properties. Temperature ranges for growth were determined by incubating spore suspensions on slants of CYC agar at the following temperatures: $20,28,37,45,50,55,60,62.5$, and $65^{\circ} \mathrm{C}$. Growth was recorded after 4,8 , and 14 days. All of the other tests were then carried out at the optimum temperature for each strain. Growth at $\mathrm{pH} 6.0$ and 11.0 was determined by using CYC agar as the basal medium.

Formation of melanin was determined on complex peptone-yeast extract-iron agar (58) and on a synthetic agar medium containing $\mathrm{CuSO}_{4}$ with and without tyrosine (19).

The following physiological tests were performed by using previously described methods: resistance to lysozyme (35); nitrate reduction (26); hydrolysis of esculin, arbutin, urea, and allantoin with final concentrations of $\beta$-glycosides, urea, and allantoin of $0.1,1$, and $1 \%$, respectively (34); hydrolysis of colloidal chitin (20) and pectin (66); lipolysis of Tween 80 (17); lipolysis of tributyrin, as well as degradation of poly- $\beta$-hydroxybutyric acid and xylan (23); and lecithinase activity (egg yolk reaction) and hemolysis (26).

Resistance to sodium chloride was determined by using CYC agar as the basal medium and supplementing this medium with $4,7,10$, and $13 \%(\mathrm{wt} / \mathrm{vol}) \mathrm{NaCl}$. Resistance to kanamycin $(25 \mu \mathrm{g} / \mathrm{ml})$, novobiocin $(25 \mu \mathrm{g} / \mathrm{ml})$, and cristal violet $(0.2 \mu \mathrm{g} / \mathrm{ml})$ was determined by using CYC agar as the basal medium.

Degradation of adenine $(0.5 \%, \mathrm{wt} / \mathrm{vol})$, guanine $(0.5 \%, \mathrm{wt} / \mathrm{vol})$, xanthine $(0.4 \%, \mathrm{wt} / \mathrm{vol})$, hypoxanthine $(0.5 \%, \mathrm{wt} / \mathrm{vol})$, tyrosine $(0.5 \%$, wt $/ \mathrm{vol})$, potato starch $(1.5 \%, \mathrm{wt} / \mathrm{vol})$, casein $(1 \%$ [wt/vol] skim milk), elastin $(0.2 \%, \mathrm{wt} / \mathrm{vol})$, and gelatin $(0.4 \%$, wt/vol) was determined by using nutrient agar as the basal medium. Degradation of DNA was determined on DNase test agar (Gibco) and DNase test agar supplemented with methyl green (Difco). Cellulolytic activity was detected by using an agar medium (65) supplemented with Avicel (catalog no. 2330; Merck) as the substrate.

Utilization of carbohydrates as sole carbon sources was determined with the recommended ISP medium (58), which was modified by using SPV-4 (26) as the trace element solution. The following compounds were tested: adonitol (= ribitol), L-arabinose, cellobiose, dextrin, D-fructose, D-galactose, meso-inositol, inulin, lactose, D-mannose, D-mannitol, melezitose, melibiose, raffinose, Lrhamnose, salicin, D-sorbitol (= D-glucitol), sucrose, trehalose, xylitol, and D-xylose were each added at a concentration of $1.0 \%$ (wt/vol); and sodium acetate, sodium citrate, sodium malonate, sodium propionate, and sodium pyruvate were each added at a concentration of $0.1 \%$ (wt/vol). Utilization of the organic acids sodium citrate, sodium malonate, and oxalate was determined as described by Korn-Wendisch and Kutzner (26)

Antibiotic activity was determined by using the streak test on cornsteep agar plates (26) and the following organisms: Escherichia coli B strain DSM 613, Corynebacterium glutamicum DSM $20300^{\mathbf{T}}$, Rhodococcus rhodochrous DSM 43202, Bacillus subtilis DSM 10 ${ }^{\mathrm{T}}$, Micrococcus luteus DSM 348, Staphylococcus aureus DSM 20231 ${ }^{\mathrm{T}}$, Candida albicans NRRL Y-477, Saccharomyces cerevisiae ATCC 2366, and Geotrichum candidum $\mathrm{Ku} 53$ (our isolate). Inhibition of Azotobacter chroococcum DSM 281 was determined by using the plate diffusion technique with M10 (3) as the test medium.

Enzyme and protein patterns. Esterases were analyzed by the methods described by Greiner-Mai et al. (15). The total protein contents were determined by using horizontal electrophoresis and $12.5 \%$ ExcelGel sodium dodecyl sulfate ready gels (Pharmacia) for separation.

Occurrence of plasmids. Plasmids were detected by the method of KornWendisch et al. (25)

Sequencing of $16 S$ rDNA. Extraction of genomic DNA, amplification of the $16 S$ rRNA gene by the PCR, and purification of the resulting PCR products were performed as previously described $(50,51)$. The double-stranded $16 \mathrm{~S}$ ribosomal DNA (rDNA) PCR products were sequenced by using a Taq DyeDeoxy terminator cycle sequencing kit (Applied Biosystems).

Analysis of 16S rDNA sequences. The 16S rDNA sequences were manually aligned with homologous 16 SDNA sequences of actinomycetes obtained from the Ribosomal Database Project (38) and recent databank entries. Initially, the sequences of the isolates were compared with the sequences of representatives of the main lines of descent. Because of the presence of unsequenced 16S rDNA stretches in reference strains, the following regions ( $E$. coli nomenclature [5]) were not used when we determined similarity values and pairwise evolutionary distances (21): position 1 to position 184 and position 1354 to the $3^{\prime}$ terminus. The least-squares distance method of De Soete (9) was used in the construction of phylogenetic dendrograms from distance matrices.

Chemotaxonomic markers. The cells used for chemical analyses were grown in GPYB broth (16). The isomer of diaminopimelic acid (DAP) and the sugars in whole-cell hydrolysates were determined by using the methods of Becker et al. (2) and Lechevalier and Lechevalier (41), as modified by Stanek and Roberts (60) for separation on thin-layer plates. Mycolic acids were analyzed as described by Minnikin et al. (46). Phospholipids were extracted and identified by using the methods of Minnikin et al. (47). Menaquinones were extracted and purified as described by Collins et al. (6) and were identified by high-performance liquid chromatography $(29,30)$.

To extract and analyze fatty acids, $40 \mathrm{mg}$ (wet weight) of cells was used for saponification (45); the resulting sodium salts of the fatty acids were methylated, and the methyl esters were extracted. The fatty acid methyl esters were analyzed by automated gas-liquid chromatography with a model HP5898A microbial identification system (Hewlett-Packard Co., Avondale, Pa.). The cellular fatty acid methyl esters were identified by comparing their retention times with the retention times of known standards and by calculating equivalent chain lengths with a computer. The software used for the numerical analysis and for the construction of the dendrogram was obtained from Microbial ID, Inc., Newark, Del.

DNA base composition. DNA was isolated by a modified phenol method (49), using RNase $A$ and RNase $T_{1}$. The guanine-plus-cytosine $(G+C)$ content of DNA was determined by high-performance liquid chromatography (62)

Phage typing. Phages were isolated and propagated and phage typing was performed by using previously described methods $(24,27)$. The following sets of phages were used: (i) phages W2 and W4 for Amycolatopsis mediterranei, phages W7 and W11 for Amycolatopsis orientalis, phage Tm1 for Saccharomonospora viridis, and phage $\mathrm{W} 1$ for Saccharothrix aerocoligenes were kindly provided by $\mathrm{H}$. Prauser (Jena, Germany), and phage SE6 for Saccharopolyspora spp. was kindly supplied by C. R. Hutchinson (Madison, Wis.); (ii) the other phages for the genera Pseudonocardia, Saccharomonospora, and Saccharopolyspora were isolated in our laboratory (Institut für Mikrobiologie, Darmstadt) from plant compost, waste compost, and soils obtained from Germany, Argentina, and Tenerife, as well as lysogenic cultures; and (iii) six phages were isolated for isolates MKD8, MKD10, MKD19, MKD35 ${ }^{\mathrm{T}}$, MKD38, and $\mathrm{CHB} 77^{\mathrm{T}}$ by enrichment procedures from the compost samples from which the organisms had been obtained.

Nucleotide sequence accession numbers. The 16S rDNA sequences of strains $\mathrm{CHB}_{77^{\mathrm{T}}}, \mathrm{MKD} 35^{\mathrm{T}}$, and MKD19 have been deposited in the EMBL database under accession numbers X79183, X79184, and X79185, respectively.

\section{RESULTS AND DISCUSSION}

Cultural characteristics. Good growth of all 10 new isolates was obtained on the following media: CYC agar, GYM agar, Hickey-Tresner agar, oatmeal agar, potato-carrot agar, PM agar, R2A agar, R8 agar, and TSA. Poor growth was observed only on glycerol-arginine agar. All strains produced abundant white aerial mycelium and yellow to light brown substrate 
TABLE 1. Morphological characteristics of our isolates, genera belonging to the family Pseudonocardiaceae, the genus Saccharothrix, and some other type III cell wall actinomycetes ${ }^{a}$

\begin{tabular}{|c|c|c|c|}
\hline Taxon & Aerial mycelium color(s) & Arrangement of aerial mycelium & Spore surface \\
\hline Our isolates & White & $\begin{array}{l}\text { Long chains, pseudosporangia fragmenting into } \\
\text { rod-like structures }\end{array}$ & Smooth \\
\hline Actinopolyspora & White & Long straight chains & Smooth \\
\hline Amycolatopsis & White (sparse) & $\begin{array}{l}\text { Long chains, squarish to oval fragments, spore- } \\
\text { like structures }\end{array}$ & Smooth \\
\hline Kibdelosporangium & White & Long chains, sporangium-like structures & Smooth \\
\hline Pseudonocardia & White & $\begin{array}{l}\text { Zig-zag-shaped, budding, long chains, } \\
\text { fragmenting into squarish to oval fragments }\end{array}$ & Smooth, spiny \\
\hline Saccharomonospora & Green, violet & Single densely packed spores & Smooth, warty \\
\hline Saccharopolyspora & White, pink to brownish gray & $\begin{array}{l}\text { Short and long chains, straight, loops, and } \\
\text { spirals }\end{array}$ & $\begin{array}{l}\text { Smooth, roughened, } \\
\text { hairy, spiny }\end{array}$ \\
\hline Saccharothrix & White to yellowish gray & $\begin{array}{l}\text { Long chains, fragmenting into coccoid } \\
\text { elements }\end{array}$ & Smooth \\
\hline Kutzneria & White, olive gray & $\begin{array}{l}\text { Globose sporangia with coiled, unbranched } \\
\text { hyphae forming sporangiospores by septation }\end{array}$ & No data \\
\hline Actinomadura & $\begin{array}{l}\text { If present, white, yellow, } \\
\text { pink, blue, green, gray }\end{array}$ & $\begin{array}{l}\text { Short and long chains, straight, loops, and } \\
\text { spirals, pseudosporangia (several species) }\end{array}$ & $\begin{array}{l}\text { Smooth, warty, } \\
\text { spiny, uneven }\end{array}$ \\
\hline Microtetraspora & White to pale pink, blue-gray & $\begin{array}{l}\text { Chains of typically four spores, short and long } \\
\text { chains, straight, loops, or irregular spirals, } \\
\text { forming pseudosporangia }\end{array}$ & Smooth, warty \\
\hline Nocardiopsis & $\begin{array}{l}\text { White to yellowish gray } \\
\text { ("griseus") }\end{array}$ & $\begin{array}{l}\text { Long, straight, flexuous or zig-zag-shaped } \\
\text { hyphae, completely fragmenting into spores }\end{array}$ & Smooth \\
\hline Thermomonospora & White & $\begin{array}{l}\text { Single densely packed spores sessile or on } \\
\text { sporophores }\end{array}$ & Smooth, spiny \\
\hline
\end{tabular}

${ }^{a}$ Data from references $13-15,25,28,32,36,42-44,48,57$, and 59 and our study.

mycelium on CYC agar and potato-carrot agar. No characteristic diffusible pigments were detected. Sparse to moderate aerial mycelium was formed on TSA, GYM agar, oatmeal agar, PM agar, and R2A agar.

Morphology. The morphological characteristics of the 10 new isolates, of the genera belonging to the family Pseudonocardiaceae, of the genus Saccharothrix, and of some other type III cell wall actinomycetes are summarized in Table 1 . The surfaces of colonies were covered with straight to flexuous aerial hyphae, and both substrate and aerial mycelia often formed aggregates (Fig. 1). The aerial mycelia fragmented into rod-like structures (Fig. 2). Furthermore, pseudosporangia similar to the sporangium-like structures of Kibdelosporangium strains were observed in all strains. These pseudosporangia, however, were not surrounded by a well-defined wall and contained septate hyphae which fragmented into rod-like structures (Fig. 3).

Physiology. The temperature ranges and variable and differentiating physiological properties of the isolates are shown in Table 2. All 10 new strains grew well at temperatures ranging from 28 to $60^{\circ} \mathrm{C}$ and at $\mathrm{pH} 6.0$ and 11.0 , were resistant to $5 \%$ $\mathrm{NaCl}$ when the basal medium was GYM agar or TSA, were resistant to novobiocin and cristal violet, formed nitrite under aerobic conditions, degraded casein, tyrosine, gelatin, and DNA, hydrolyzed esculin, and lipolyzed Tween 80 and tributyrin. Pectin was degraded weakly, and arbutin was hydrolyzed slowly. In contrast, none of the 10 strains hydrolyzed or degraded chitin, adenine, hypoxanthine, xanthine, poly- $\beta$-hydroxybutyric acid, starch, xylan, urea, and allantoin. The strains did not produce melanin, exhibited no cellulolytic activity, and were susceptible to lysozyme.

All of the strains utilized the following carbohydrates: glucose, galactose, mannose, cellobiose, sucrose, trehalose, inositol, dextrin, sodium malonate, and sodium pyruvate. None of the strains tested utilized xylose, rhamnose, lactose, melibiose, raffinose, adonitol ( $=$ ribitol), xylitol, inulin, sodium propionate, and oxalate. Melezitose, mannitol, and sorbitol (= glucitol) were poor substrates, and the results obtained with these compounds were often equivocal.

None of the 10 isolates exhibited antibiotic activity against $E$. coli, Corynebacterium glutamicum, B. subtilis, and Staphylococcus aureus. One isolate $\left(\mathrm{CHB} 77^{\mathrm{T}}\right)$ was slightly active against $R$. rhodochrous and Micrococcus luteus and inhibited Azotobacter chroococcum, Candida albicans, Saccharomyces cerevisiae, and G. candidum.

Enzyme and protein patterns. Our analysis of esterases revealed the following four basic patterns for the 10 isolates: (i) five strains (MKD10, MKD19, MKD35 ${ }^{\mathrm{T}}, \mathrm{MKD} 38$, and MKD57) had a major band at an $R_{f}$ of 0.71 to 0.73 and minor bands at $R_{f}$ values of 0.5 to 0.52 and 0.59 to 0.62 ; (ii) three strains (TMK2, TMS14, and TMD78) were characterized by a major band at an $R_{f}$ of 0.75 to 0.78 and minor bands at $R_{f}$ values of 0.5 to 0.52 and 0.59 to 0.62 ; (iii) strain MKD8 produced two major bands at $R_{f}$ values of 0.5 to 0.52 and 0.59 to 0.61 and a minor band at an $R_{f}$ of 0.75 to 0.77 ; and (iv) strain CHB $77^{\mathrm{T}}$ produced only one band at an $R_{f}$ of 0.49 to 0.51 . Our analysis of the total proteins revealed clear differences between $\mathrm{CHB} 77^{\mathrm{T}}$ and the other nine strains. The protein patterns of these nine strains varied only slightly, corresponding to the first three groups obtained in the analysis of esterase patterns described above.

Occurrence of plasmids. The optimal concentrations of glycine and lysozyme were $0.1 \%$ and $2 \mathrm{mg} / \mathrm{ml}$, respectively, and the optimal incubation time in lysozyme was determined for each strain. Only one plasmid (about $35 \mathrm{~kb}$ ) was detected in MKD19.

Phylogenetic analysis. The 16S rDNA sequences of strains MKD19, MKD35 ${ }^{\mathrm{T}}$, and $\mathrm{CHB} 77^{\mathrm{T}}$ were analyzed and compared with the sequences of actinomycete taxa. These three isolates were closely related to each other (levels of homology, $>97.7 \%$ ) (Table 3 and Fig. 4) and to members of the family Pseudonocardiaceae and related taxa, including Kutzneria viri- 

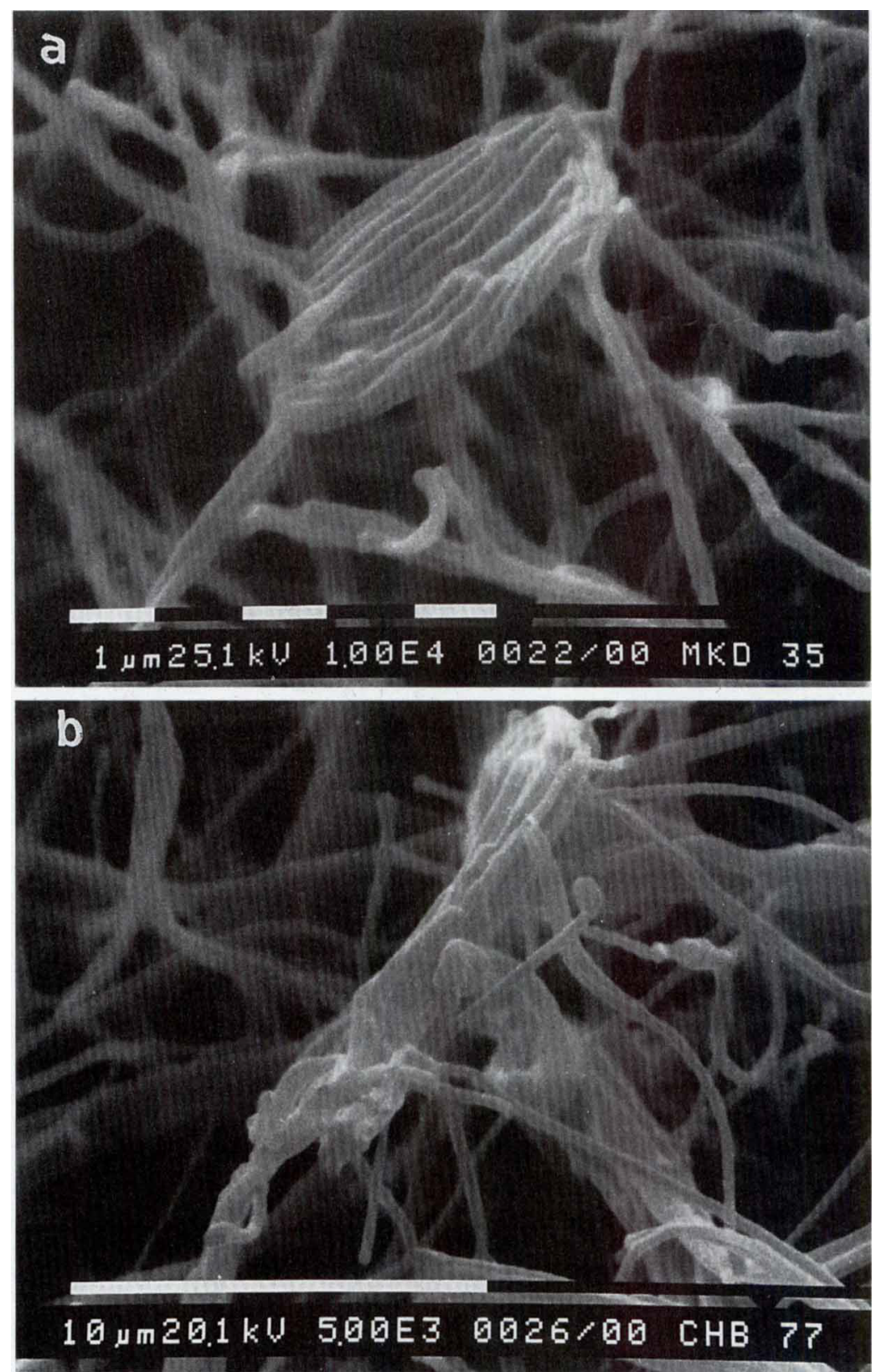

FIG. 1. Scanning electron micrographs of aerial mycelia. (a) Isolate MKD35 ${ }^{\mathrm{T}}$. Magnification, $\times 10,000$. (b) Isolate $\mathrm{CHB77} \mathrm{T}^{\mathrm{T}}$. Magnification, $\times 5,000$.

dogrisea, Saccharothrix australiensis, Actinokineospora riparia, and Actinosynnema pretiosum (levels of homology, 92.8 to 95.6\%) (Table 3 and Fig. 4) (data for Actinosynnema pretiosum are not shown; the sequence of this species was kindly provided by T. M. Embley). The topology of the phylogenetic tree in Fig. 4 is similar to the topology of the tree published previously (64) in that Saccharothrix australiensis and Actinokineospora riparia (as well as Kutzneria viridogrisea, which was not available for the study of Warwick et al. [64]) form a sister group related to the genus Amycolatopsis. As discussed by Warwick et al. (64), the distribution of cell wall types does not match the phylogenetic clustering of the family Pseudonocardiaceae, the genus Actinokineospora (chemotype IV), and the genus Saccharothrix and its relatives (chemotype III). A decision concerning whether to include all of the organisms shown in Fig. 4, irrespective of the occurrence of different wall types in a single family, or to maintain the separation of taxa primarily on the basis of wall types should be postponed until more sequences and hence a more stable topology are available. For the purposes of this study it was mainly important to demonstrate the phylogenetic uniqueness of the new isolates.

Chemotaxonomic markers. The chemotaxonomic properties of our 10 isolates, of the genera belonging to the family Pseudonocardiaceae, of the genus Saccharothrix, and of some other type III cell wall actinomycetes are summarized in Table 4. All of our isolates had cell wall type III of Lechevalier et al. (39) (meso-DAP in the peptidoglycan and type C whole-cell sugar pattern with arabinose, mannose, and glucose); only traces of galactose were found in some strains. According to Embley (11), the family Pseudonocardiaceae is characterized by 

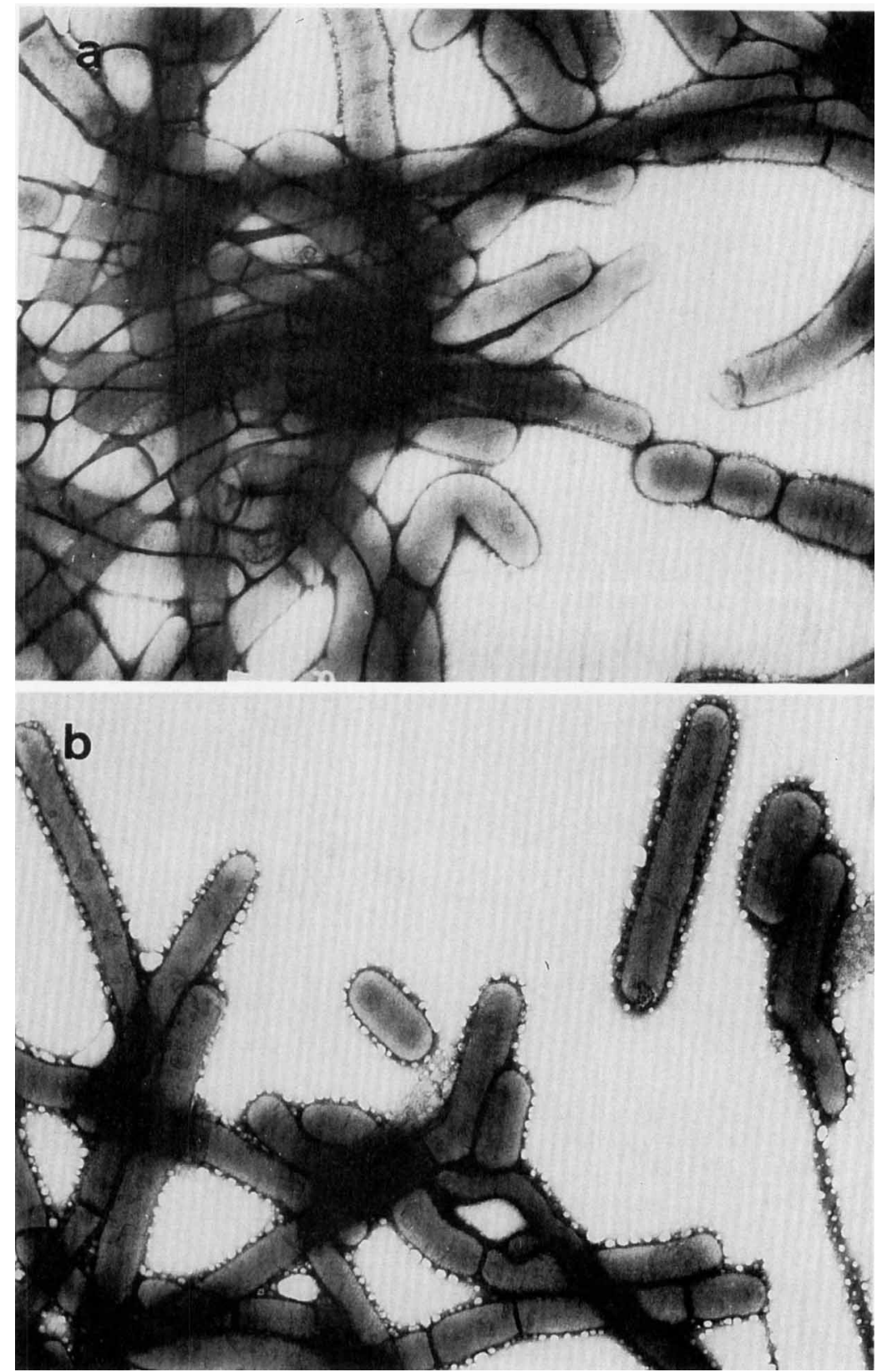

FIG. 2. Transmission electron micrographs of aerial mycelia. (a) Isolate MKD35 ${ }^{\mathbf{T}}$. Magnification, $\times 25,000$. (b) Isolate $\mathrm{CHB}^{\mathrm{N}} \mathrm{M}^{\mathbf{T}}$. Magnification, $\times 25,000$.

cell wall type IV (meso-DAP and sugar type A, with arabinose and galactose as the diagnostic sugars), whereas members of the genera Saccharothrix and Kutzneria contain meso-DAP and the diagnostic whole-cell sugars galactose and rhamnose (sugar type E, as defined by Kroppenstedt [31]). However, arabinose and galactose have recently been reported to be present in whole-cell hydrolysates of Saccharothrix longispora and Saccharothrix syringae (61). No mycolic acids were detected in our isolates or members of the reference genera.

All 10 of our isolates produced similar phospholipid patterns containing phosphatidylethanolamine, phosphatidylinositol, hydroxyphosphatidylethanolamine, and an unknown ninhydrin-positive lipid; i.e., the phospholipid type was type PII (40). This phospholipid pattern is also found in the genera Saccharothrix and Kutzneria and in some genera of the family Pseudonocardiaceae, including the genera Amycolatopsis, Kibdelosporangium, and Saccharomonospora. The predominant menaquinone (95 to $100 \%$ ) in our 10 isolates was MK- $9\left(\mathrm{H}_{4}\right)$. The $\mathrm{G}+\mathrm{C}$ contents of the DNAs of 9 of the 10 isolates ranged from 69 to $70 \mathrm{~mol} \%$; the $\mathrm{G}+\mathrm{C}$ content of MKD19 was 73 mol\%.

The fatty acid compositions of our 10 isolates, of the genera belonging to the family Pseudonocardiaceae, of the genera Saccharothrix and Kutzneria, and of some other type III cell wall actinomycetes are summarized in Table 5. All 10 of our isolates produced qualitatively similar fatty acid profiles, which consisted of mainly iso-branched saturated and 2-hydroxy fatty acids (fatty acid type 3f); iso-, anteiso-, and 10-methylbranched fatty acids were found in smaller amounts $(0.5$ to $5 \%$ ). The dendrogram in Fig. 5 shows the relationships among 

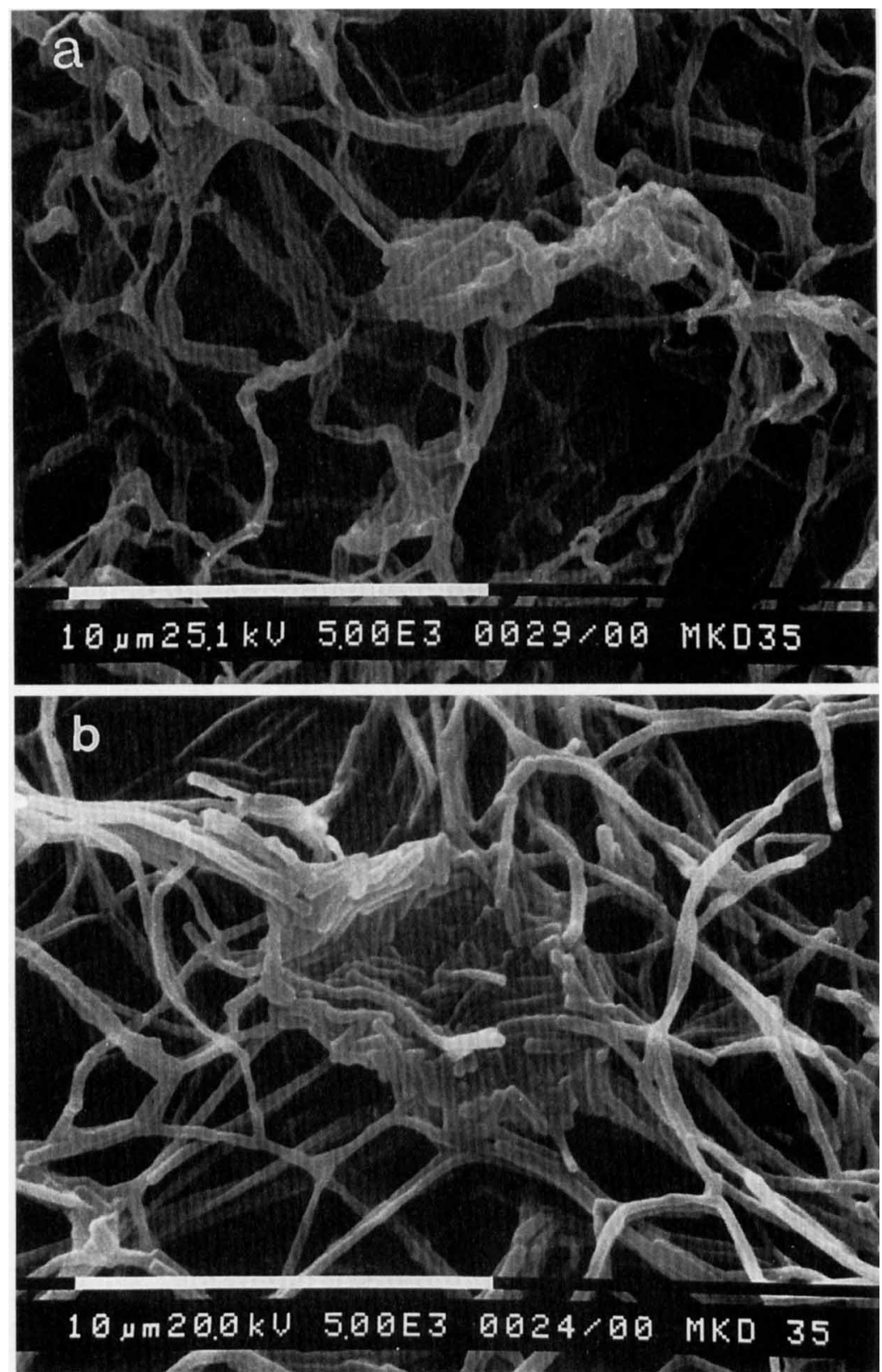

FIG. 3. Scanning electron micrographs of isolate $M K D 35^{T}$. (a) Pseudosporangia. Magnification, $\times 5,000$. (b) Pseudosporangium containing septate hyphae which fragmented into rodlike structures.

our isolates, the genus Saccharothrix, and the genera of the family Pseudonocardiaceae as determined by a numerical analysis of their fatty acids.

Phage typing. The host range patterns of the three sets of actinophages tested (46 phages) showed that none of the phages could cross genus boundaries, even if high phage titers were used. Furthermore, our results demonstrated again the feasibility of using actinophages for host identification at the genus level, which was confirmed by biochemical and molecular characterization data $(11,25)$. In most cases, sensitivity to phages even provided unequivocal evidence of affiliation of the different species with their corresponding genera. The specificity of actinophages at the genus level was also confirmed with the phages isolated for six of our isolates; no positive reaction was observed with strains belonging to the genera of the Pseudonocardiaceae, the genus Saccharothrix, and some other type III cell wall actinomycetes.

On the basis of their patterns of sensitivity to the phages, our 10 isolates could be separated into two main groups, as follows: (i) one isolate $\left(\mathrm{CHB} 77^{\mathrm{T}}\right)$ was lysed by its corresponding phage, $\phi 77$, but was sensitive only to two of the five phages isolated for strains MKD8, MKD10, MKD19, MKD35 ${ }^{\mathrm{T}}$, and MKD38 if high phage titers were used; and (ii) in contrast, only four of the nine other isolates were lysed by a high titer of $\phi 77$. Furthermore, the latter nine isolates formed three subgroups, as follows: (i) three of these strains were lysed by all five phages isolated for strains MKD8, MKD10, MKD19, MKD35 ${ }^{\mathrm{T}}$, and MKD38; (ii) two strains (TMS14 and MKD38) were not lysed by $\phi 10$ even if high phage titers were used, and one strain $\left(\mathrm{MKD} 35^{\mathrm{T}}\right)$ was lysed by this phage only if a high phage titer 
TABLE 2. Physiological characteristics of the new isolates

\begin{tabular}{|c|c|c|}
\hline Characteristic & $\begin{array}{l}\text { Isolate MKD35 } \\
\text { and } 8 \text { other strains }\end{array}$ & Isolate $\mathrm{CHB} 77^{\mathrm{T}}$ \\
\hline \multicolumn{3}{|l|}{ Growth at ${ }^{a}$ : } \\
\hline $20^{\circ} \mathrm{C}$ & Weak & $\operatorname{tr}$ \\
\hline $28^{\circ} \mathrm{C}$ & +++ & ++ \\
\hline $37^{\circ} \mathrm{C}$ & +++ & +++ \\
\hline $45^{\circ} \mathrm{C}$ & +++ & +++ \\
\hline $50^{\circ} \mathrm{C}$ & +++ & +++ \\
\hline $55^{\circ} \mathrm{C}$ & +++ & +++ \\
\hline $60^{\circ} \mathrm{C}$ & $+t$ & +++ \\
\hline $62.5^{\circ} \mathrm{C}$ & $(+)$ & ++ \\
\hline $65^{\circ} \mathrm{C}$ & - & - \\
\hline \multicolumn{3}{|l|}{ Growth in the presence of ${ }^{a}$ : } \\
\hline $4 \% \mathrm{NaCl}$ & +++ & +++ \\
\hline $7 \% \mathrm{NaCl}$ & +++ & ++ \\
\hline $10 \% \mathrm{NaCl}$ & ++ & - \\
\hline $13 \% \mathrm{NaCl}$ & - & - \\
\hline $\begin{array}{l}\text { Resistance to kanamycin } \\
\quad(25 \mu \mathrm{g} / \mathrm{ml})\end{array}$ & $(+)$ & + \\
\hline \multicolumn{3}{|l|}{ Degradation of ${ }^{b}:$} \\
\hline Elastin & - & + \\
\hline Guanine & $(+)$ & - \\
\hline \multicolumn{3}{|l|}{ Utilization of ${ }^{b}$ : } \\
\hline Fructose & + & $\operatorname{tr}$ \\
\hline Maltose & + & $(+)$ \\
\hline Melezitose & $\mathrm{v}$ & $\operatorname{tr}$ \\
\hline Mannitol & $(+)$ & $\operatorname{tr}$ \\
\hline Sorbitol (= glucitol) & $\mathrm{v}$ & $\operatorname{tr}$ \\
\hline Salicin & $(+)$ & + \\
\hline Sodium acetate & t & $\operatorname{tr}$ \\
\hline Sodium citrate & $\mathrm{v}$ & - \\
\hline Hemolysis & - & + \\
\hline Egg yolk reaction & - & + \\
\hline
\end{tabular}

${ }^{a}+++$, good growth with abundant aerial mycelium; ++ , good growth with moderate aerial mycelium; $(+)$, poor growth; - , no growth.

$b+$, positive reaction; $(+)$, moderate reaction; $v$, variable; -, no reaction.

was used; and (iii) three strains (MKD10, MKD19, and MKD57) were sensitive to phages $\phi 35$ and $\phi 38$ only if high phage titers were used. These results also revealed the following problems that arise in phage typing studies: (i) more or less strong restriction barriers by some strains within a genus, as described previously for Saccharopolyspora hirsuta and Saccharopolyspora erythraea $(55,56)$ and some strains of Streptomyces coelicolor Müller (53) and also found for MKD19 and $\mathrm{CHB}_{77^{\mathrm{T}}}^{\mathrm{T}}$; (ii) occurrence of lysogeny in some strains and repression of homoimmune phages (55); and (iii) temperate phages that have the ability to lysogenize their hosts $(22,54$, 56) (this property was also observed with phage $\phi 10$, which lysogenized four of the isolates, MKD19, MKD35 ${ }^{\mathrm{T}}$, MKD57, and TMD78).

A phylogenetic analysis of 3 of our 10 isolates supported the hypothesis that they are related to the Pseudonocardiaceae, but provided clear evidence that they differ from all of the genera mentioned above. Therefore, we considered our isolates members of a new genus of the Actinomycetales, for which we propose the name Thermocrispum gen. nov. Furthermore, physiological properties, enzyme and protein patterns, and phage typing and $16 \mathrm{~S}$ rDNA data showed that the new genus contains two species.

Description of the genus Thermocrispum gen. nov. Thermocrispum (Ther.mo.cris' pum. Gr. adj. thermos, warm, hot; L. neut. adj. crispum, tightly curled; N.L. neut. n. Thermocrispum, a heat-loving, tightly curled organism). Strains are grampositive, aerobic, catalase-positive, non-acid-fast, thermophilic

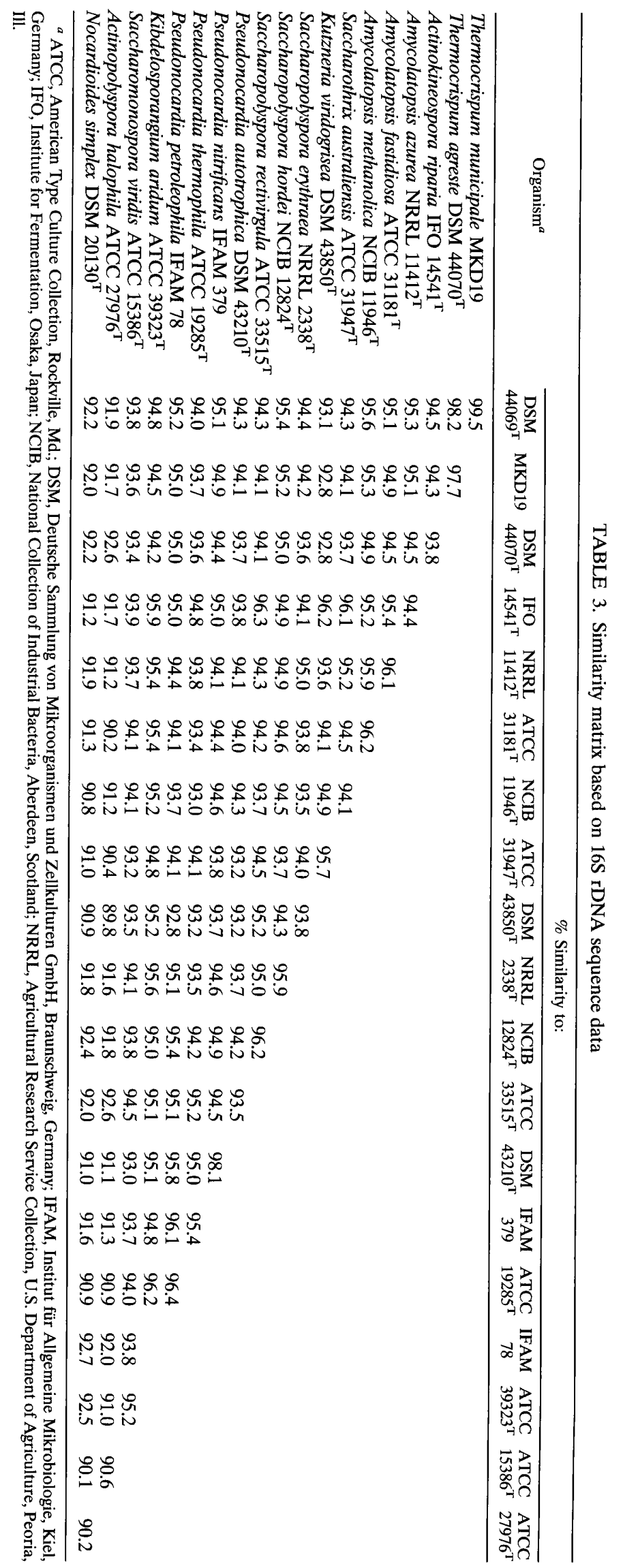




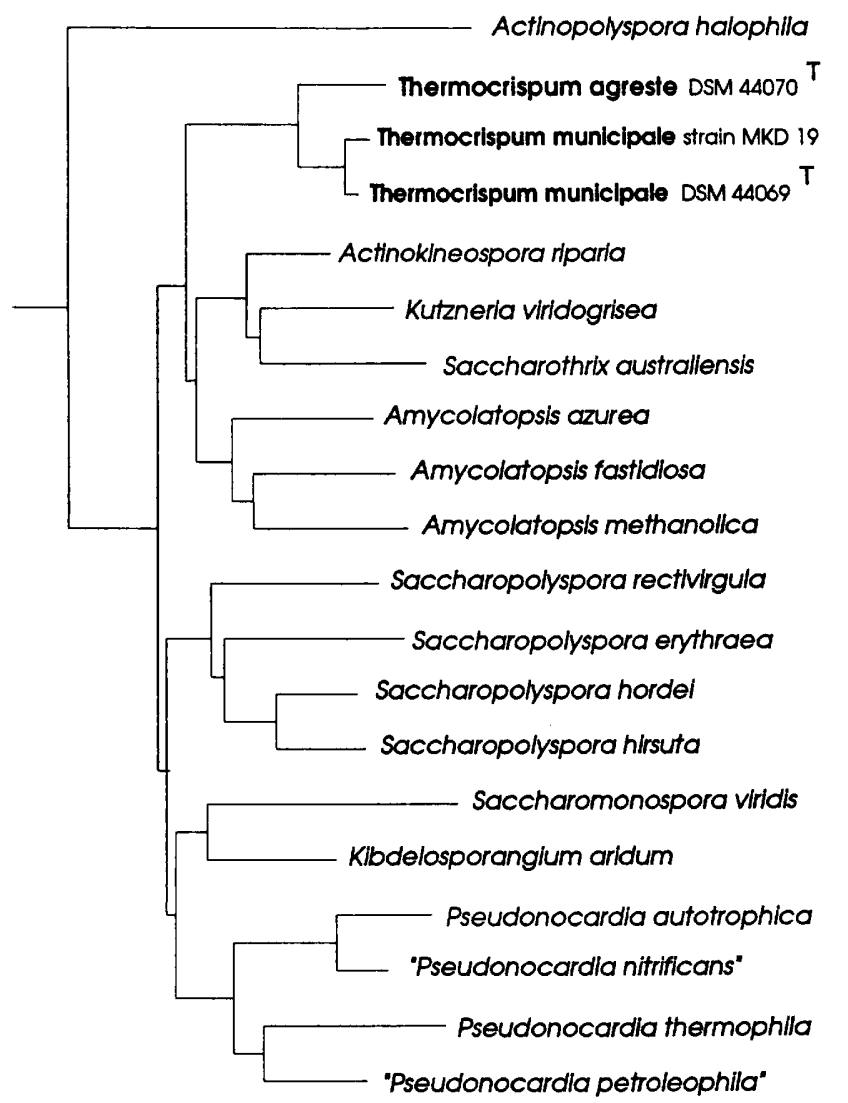

$2 \%$

FIG. 4. Phylogenetic tree showing the relationships among the isolates described as Thermocrispum species in this study and other actinomycetes. A more detailed phylogenetic tree for the reference organisms has been published by Warwick et al. (64). organisms which produce filamentous, branched hyphae. The aerial mycelium is white, and the vegetative mycelium is yellow to light brown. No soluble pigment is produced. Aerial hyphae are straight to flexuous and often aggregate into clusters, so-called pseudosporangia, which fragment into rod-like structures; true sporangia are not observed.

The organisms grow well on CYC agar, GYM agar, HickeyTresner agar, oatmeal agar, potato-carrot agar, PM agar, R2A agar, and R8 agar, as well as TSA. The temperature range for growth is 20 to $62.5^{\circ} \mathrm{C}$, and the optimum temperature for growth is 45 to $55^{\circ} \mathrm{C}$. Growth occurs at $\mathrm{pH} 6.0$ and 11.0. The strains grow in the presence of $5 \% \mathrm{NaCl}$, novobiocin, and cristal violet. Nitrate is reduced to nitrite under aerobic conditions. The strains degrade or hydrolyze casein, tyrosine, gelatin, DNA, and esculin, and lipolysis of Tween 80 and tributyrin occurs. Chitin, adenine, hypoxanthine, xanthine, poly- $\beta$-hydroxybutyric acid, starch, and xylan are not degraded or hydrolyzed. Urea and allantoin are not hydrolyzed. Melanoid pigment is not produced. No cellulolytic activity occurs. Not resistant to lysozyme. Glucose, galactose, mannose, cellobiose, sucrose, trehalose, inositol, dextrin, sodium malonate, and sodium pyruvate are utilized as sole carbon sources, but xylose, rhamnose, lactose, melibiose, raffinose, adonitol $(=$ ribitol), xylitol, inulin, and sodium propionate are not utilized. Melezitose, mannitol, and sorbitol (= glucitol) are poor substrates and may or may not be utilized as sole carbon sources.

The cell wall contains meso-DAP, and the whole-cell sugar pattern type is type $\mathrm{C}$; major amounts of arabinose, mannose, and glucose are present, and only traces of galactose are detected. Phospholipid type PII. No mycolic acids are present. The predominant menaquinone is $\mathrm{MK}-9\left(\mathrm{H}_{4}\right)$. The $\mathrm{G}+\mathrm{C}$ contents of the DNAs range from 69 to $73 \mathrm{~mol} \%$. Resistant to a set of phages for the genera Amycolatopsis, Pseudonocardia, Saccharomonospora, Saccharopolyspora, and Saccharothrix. Sensitive to genus-specific phages isolated from different habitats.

The genus is related to members of the Pseudonocardiaceae and to the genera Saccharothrix, Kutzneria, and Actinokineospora.

The type species is Thermocrispum municipale.

Description of Thermocrispum municipale sp. nov. Thermocrispum municipale (mu.ni.ci.pa' le. L. neut. adj. municipale,

TABLE 4. Chemotaxonomic markers of our isolates, genera belonging to the family Pseudonocardiaceae, the genus Saccharothrix, and some other type III cell wall actinomycetes ${ }^{a}$

\begin{tabular}{|c|c|c|c|c|c|c|c|c|c|c|c|c|c|c|c|c|c|c|}
\hline \multirow[b]{2}{*}{ Taxon } & \multirow{2}{*}{$\begin{array}{c}\text { DAP } \\
\text { isomer }\end{array}$} & \multirow{2}{*}{$\begin{array}{c}\text { Cell wall } \\
\text { type }\end{array}$} & \multirow{2}{*}{$\begin{array}{c}\text { Whole- } \\
\text { cell } \\
\text { sugar } \\
\text { type }^{b}\end{array}$} & \multicolumn{6}{|c|}{ Phospholipids ${ }^{c}$} & \multirow{2}{*}{$\begin{array}{l}\text { Phospho- } \\
\text { lipid } \\
\text { type }\end{array}$} & \multicolumn{7}{|c|}{ Amt of the following menaquinones ${ }^{d}$ : } & \multirow{2}{*}{$\begin{array}{c}\mathrm{G}+\mathrm{C} \\
\text { content } \\
(\mathrm{mol} \%)\end{array}$} \\
\hline & & & & $\mathrm{PE}$ & $\mathrm{PC}$ & PI & PIM & $\mathrm{OHP}$ & NPG & & $\begin{array}{l}\text { MK-8 } \\
\left(\mathrm{H}_{4}\right)\end{array}$ & $\begin{array}{c}\text { MK-9 } \\
\left(\mathrm{H}_{2}\right)\end{array}$ & $\underset{\left(\mathrm{H}_{4}\right)}{\text { MK-9 }}$ & $\begin{array}{c}\text { MK-9 } \\
\left(\mathrm{H}_{6}\right)\end{array}$ & $\begin{array}{c}\text { MK-9 } \\
\left(\mathrm{H}_{8}\right)\end{array}$ & $\underset{\left(\mathrm{H}_{4}\right)}{\mathrm{MK}-10}$ & $\underset{\left(\mathrm{H}_{6}\right)}{\mathrm{MK}-10}$ & \\
\hline Our isolates & meso & III & $\mathrm{C}(\mathrm{A})$ & + & - & + & - & + & - & PII & - & - & +++ & +- & - & - & - & $69-73$ \\
\hline Actinopolyspora & meso & IV & A & - & + & + & + & - & - & PIII & - & - & ++ & ++ & - & - & - & 64 \\
\hline Amycolatopsis & meso & IV & A & + & - & + & + & + & - & PII & - & + & +++ & - & - & - & - & $66-69$ \\
\hline Kibdelosporangium & meso & IV & A (B) & + & - & $(+)$ & $(+)$ & + & - & PII & - & - & ++++ & +- & - & - & - & 66 \\
\hline Pseudonocardia & meso & IV & A & + & + & + & + & + & - & PIII & ++++ & - & - & - & - & - & - & $68-79$ \\
\hline Saccharomonospora & meso & IV & A & + & - & + & + & + & - & PII & ++ & - & +++ & - & - & - & - & $66-70$ \\
\hline Saccharopolyspora & meso & IV & A & + & + & + & + & $v$ & - & PIII & - & + & +++ & - & - & + & - & $70-71.5$ \\
\hline Saccharothrix & meso & III & $\mathrm{E}$ & + & - & + & + & - & - & PII & - & - & +++ & - & - & + & - & $70-73$ \\
\hline Kutzneria & meso & III & $\mathbf{E}$ & + & - & + & $(+)$ & + & - & PII & - & - & ++++ & +- & - & - & - & $70.3-70.7$ \\
\hline Actinomadura & meso & III & B & - & - & + & + & - & - & PI & - & - & + & +++ & ++ & - & - & $66-70$ \\
\hline Microtetraspora & meso & III & B (C) & + & - & + & + & + & + & PIV & - & ++ & $++t$ & (v) & - & - & - & $66-69$ \\
\hline Nocardiopsis & meso & III & $\mathrm{C}$ & + & + & + & + & - & - & PIII & - & - & $\mathrm{v}$ & $\mathrm{v}$ & $\mathrm{v}$ & $++t$ & $+t$ & $64-69$ \\
\hline Thermomonospora & meso & III & $\mathrm{C}(\mathrm{B})$ & - & - & + & + & - & - & PI & - & - & + & +++ & ++ & - & - & $66-70$ \\
\hline
\end{tabular}

${ }^{a}$ Data from references $11,25,31,59$, and 32 and our study.

${ }^{b}$ (A), traces of galactose are present in some strains; A (B), traces of madurose are present in some strains in addition to arabinose and galactose; B (C), some strains lack madurose; $\mathrm{C}(\mathrm{B})$, traces of madurose are present in some strains.

${ }^{c}$ Abbreviations: PE, phosphatidylethanolamine; PC, phosphatidylcholine; PI, phosphatidylinositol; PIM, phosphatidylinositol mannoside; OHP, hydroxyphosphatidylethanolamine; NPG, $N$-phosphatidylglycerol. + , present; - , absent; $(+)$, present in only trace amounts; $v$, variable.

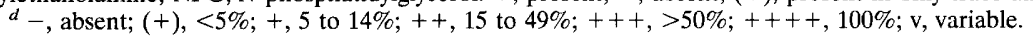


TABLE 5. Fatty acid compositions of our isolates, genera.belonging to the family Pseudonocardiaceae, the genus Saccharothrix, and some other type III cell wall actinomycetes

\begin{tabular}{|c|c|c|c|c|c|c|c|}
\hline \multirow[b]{2}{*}{ Taxon } & \multicolumn{6}{|c|}{ Fatty acid composition $^{a}$} & \multirow{2}{*}{$\begin{array}{c}\text { Fatty acid } \\
\text { type }^{b}\end{array}$} \\
\hline & iso-16:0 & iso-17:0 & anteiso-17:0 & $17: 1$ & $\begin{array}{c}\text { 10-Methyl } \\
17: 0\end{array}$ & $2 \mathrm{OH}$ & \\
\hline Our isolates & ++++ & $(+)$ & $(+)$ & + & $(+)$ & ++ & $3 f$ \\
\hline Actinopolyspora & + & + & ++ & - & - & - & $2 \mathrm{e}$ \\
\hline Amycolatopsis & ++++ & + & + & ++ & + & + & $3 f$ \\
\hline Kibdelosporangium & ++ & + & $(+)$ & + & $\operatorname{tr}$ & + & $3 f$ \\
\hline Pseudonocardia & ++ & ++ & $+t$ & + & $\operatorname{tr}$ & + & $3 f$ \\
\hline Saccharomonospora & +++ & + & + & + & - & ++ & $2 a$ \\
\hline Saccharopolyspora & ++ & ++ & ++ & - & + & $\mathrm{v}$ & $3 \mathrm{e}$ \\
\hline Saccharothrix & $+t+t$ & + & ++ & + & + & + & $3 f$ \\
\hline Kutzneria & $++t+$ & ++ & ++ & + & $+t$ & ++ & $3 c$ \\
\hline Actinomadura & ++ & - & - & + & + & - & $3 a$ \\
\hline Microtetraspora & +++ & + & + & + & ++ & ++ & $3 c$ \\
\hline Nocardiopsis & +++ & + & +++ & + & ++ & - & $3 \mathrm{~d}$ \\
\hline Thermomonospora & ++ & - & - & + & + & - & $3 a$ \\
\hline
\end{tabular}

${ }^{a}$-, absent; $(+),<1 \% ;+, 1$ to $5 \% ;++, 5$ to $15 \% ;+++, 15$ to $25 \% ;++++,>25 \%$; v, variable; tr, trace. $2 \mathrm{OH}$, 2-hydroxy fatty acids.

${ }^{b}$ Fatty acid types as defined by Kroppenstedt (30).

municipal, referring to the environment from which strains were isolated). The morphological, general physiological, and chemotaxonomic characteristics of Thermocrispum municipale are the same as those given above for the genus. In addition, growth occurs in the presence of $10 \% \mathrm{NaCl}$. Moderately resistant to kanamycin. Elastin is not degraded, and guanine is moderately degraded. Fructose, maltose, and sodium acetate are utilized as sole carbon sources, mannitol and salicin are weakly utilized, and melezitose, sorbitol (= glucitol), and sodium citrate may or may not be utilized. No hemolysis occurs, and there is no egg yolk reaction.

Isolated from municipal waste compost, air of compost plants, and air of a refuse incineration plant in the south of Germany. The type strain of Thermocrispum municipale is MKD35 (= DSM 44069).

Description of Thermocrispum agreste sp. nov. Thermocrispum agreste (a.gre' ste. L. neut. adj. agreste, rural, referring to the origin of the compost from which the organism was

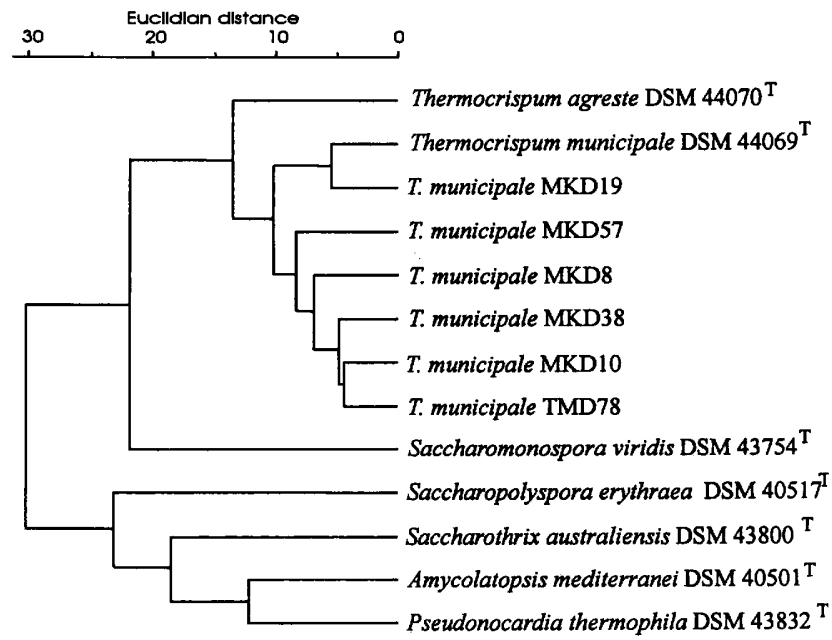

FIG. 5. Cluster analysis of the fatty acid profiles of the new isolates and some members of the Pseudonocardiaceae. The branching pattern was constructed from Euclidian distance coefficients by the unweighted pair group method with arithmetic averages. The analysis was performed by using the standard Microbial Identification System software (Microbial ID, Inc., Del.). isolated). The morphological, general physiological, and chemotaxonomic characteristics of Thermocrispum agreste are the same as those given above for the genus. Growth occurs in the presence of up to $7 \% \mathrm{NaCl}$. Resistant to kanamycin. Elastin is degraded, but guanine is not degraded. Salicin is utilized as a sole carbon source, and maltose is weakly utilized, but sodium citrate is not utilized. Only traces of growth occur in the presence of fructose, melezitose, mannitol, sorbitol (= glucitol), and sodium acetate as sole carbon sources. Hemolytic activity and egg yolk positive. Slightly active against the gram-positive bacteria $R$. rhodochrous and Micrococcus luteus and active against Azotobacter chroococcum, Candida albicans, Saccharomyces cerevisiae, and $G$. candidum.

Isolated from mushroom compost used by a mushroom cultivator in Beerfelden, Germany. The type strain of Thermocrispum agreste is CHB77 (= DSM 44070).

\section{ACKNOWLEDGMENTS}

We thank Gabriele Liebing and Angelika Lieke for technical assistance, K.-D. Jahnke for determining the G+C contents of DNAs, and Detlef Kramer for taking the transmission electron micrographs.

This work was supported by grants $01 \mathrm{HK} 458 / 0$ and $01 \mathrm{HK} 739$ from the Bundesministerium für Forschung und Technologie, Germany.

\section{REFERENCES}

1. Amner, W., C. Edwards, and A. J. McCarthy. 1989. Improved medium for recovery and enumeration of the farmer's lung organism, Saccharomonospora viridis. Appl. Environ. Microbiol. 55:2669-2674.

2. Becker, B., M. P. Lechevalier, and H. A. Lechevalier. 1965. Chemical composition of cell-wall preparations from strains of various form-genera of aerobic actinomycetes. Appl. Microbiol. 13:236-243.

3. Becking, J. H. 1961. Studies on nitrogen-fixing bacteria of the genus Beijerinckia. II. Mineral nutrition and resistance to high levels of certain elements in relation to soil type. Plant Soil 14:297-322.

4. Bowen, T., E. Stackebrandt, M. Dorsch, and T. M. Embley. 1989. The phylogeny of Amycolata autotrophica, Kibdelosporangium aridum and Saccharothrix australiensis. J. Gen. Microbiol. 135:2529-2536.

5. Brosius, J., J. J. Palmer, J. P. Kennedy, and H. F. Noller. 1978. Complete nucleotide sequence of a 16S ribosomal RNA gene from Escherichia coli. Proc. Natl. Acad. Sci. USA 75:4801-4805.

6. Collins, M. D., M. Goodfellow, and D. E. Minnikin. 1977. Distribution of menaquinones in actinomycetes and corynebacteria. J. Gen. Microbiol. 100:221-230.

7. Cross, T., and R. Attwell. 1974. Recovery of viable thermoactinomycete endospores from deep mud cores, p. 11-20. In A. N. Barker, G. W. Gould, and J. Wolf (ed.), Spore research 1973. Academic Press, London.

8. Cross, T., M. P. Lechevalier, and H. Lechevalier. 1963. A new genus of the Actinomycetales: Microellobosporia gen. nov. J. Gen. Microbiol. 31:421-429. 
9. De Soete, G. 1983. A least squares algorithm for fitting additive trees to proximity data. Psychometrika 48:621-626.

10. El-Nakeeb, M. A., and H. A. Lechevalier. 1963. Selective isolation of aerobic actinomycetes. Appl. Microbiol. 11:75-77.

11. Embley, T. M. 1992. The family Pseudonocardiaceae, p. 996-1027. In A. Balows, H. G. Trüper, M. Dworkin, W. Harder, and K.-H. Schleifer (ed.), The prokaryotes. Springer Verlag, Berlin.

12. Fergus, C. L. 1964 . Thermophilic and thermotolerant molds and actinomycetes of mushroom compost during peak heating. Mycologia 56:267-284.

13. Gochnauer, M. B., G. G. Leppard, P. Komaratat, M. Kates, T. Novitsky, and D. J. Kushner. 1975. Isolation and characterization of Actinopolyspora halophila gen. et sp. nov., an extremely halophilic actinomycete. Can. J. Microbiol. 21:1500-1511.

14. Goodfellow, M., J. Lacey, M. Athalye, T. M. Embley, and T. Bowen. 1989. Saccharopolyspora gregorii and Saccharopolyspora hordei: two new actinomycete species from fodder. J. Gen. Microbiol. 135:2125-2139.

15. Greiner-Mai, E., F. Korn-Wendisch, and H. J. Kutzner. 1988. Taxonomic revision of the genus Saccharomonospora and description of Saccharomonospora glauca sp. nov. Int. J. Syst. Bacteriol. 38:398-405.

16. Greiner-Mai, E., R. M. Kroppenstedt, F. Korn-Wendisch, and H. J. Kutzner. 1987. Morphological and biochemical characterization and emended description of thermophilic actinomycetes species. Syst. Appl. Microbiol. 9:97-106.

17. Harrigan, W. F., and M. E. McCance (ed.). 1966. Laboratory methods in microbiology. Academic Press, Inc. (London), Ltd., London.

18. Hasegawa, T. 1988. Actinokineospora: a new genus of the Actinomycetales. Actinomycetology 2:31-45.

19. Held, T., and H. J. Kutzner. 1990. Transcription of the tyrosinase gene in Streptomyces michiganensis DSM 40015 is induced by copper and repressed by ammonium. J. Gen. Microbiol. 136:2413-2419.

20. Hsu, S. C., and J. L. Lockwood. 1975. Powdered chitin agar as a selective medium for enumeration of actinomycetes in water and soil. Appl. Microbiol. 29:422-426.

21. Jukes, T. H., and C. R. Cantor. 1969. Evolution of protein molecules, p. 21-132. In H. N. Munro (ed.), Mammalian protein metabolism. Academic Press, Inc., New York.

22. Kempf, A., E. Greiner-Mai, J. Schneider, F. Korn-Wendisch, and H. J. Kutzner. 1987. A group of actinophages of Faenia rectivingula. Curr. Microbiol. 15:283-285.

23. Kempf, A., and H. J. Kutzner. 1989. Screening von biopolymerabbauenden Exoenzymen bei thermophilen Actinomyceten, p. 979-989. In VDLUFA (Verband Deutscher Landw. Untersuchungs- und Forschungsanstalten) Schriftenreihe 28, Kongressband 1988. VDLUFA-Verlag, Darmstadt, Germany.

24. Korn, F., B. Weingärtner, and H. J. Kutzner. 1978. A study of twenty actinophages: morphology, serological relationship and host range, p. 251270. In E. Freerksen, I. Tarnok, and J. H. Thumin (ed.), Genetics of the Actinomycetales. Gustav Fischer Verlag, Stuttgart, Germany.

25. Korn-Wendisch, F., A. Kempf, E. Grund, R. M. Kroppenstedt, and H. J. Kutzner. 1989. Transfer of Faenia rectivirgula Kurup and Agre 1983 to the genus Saccharopolyspora Lacey and Goodfellow 1975, elevation of Saccharopolyspora hirsuta subsp. taberi Labeda 1987 to species level, and emended description of the genus Saccharopolyspora. Int. J. Syst. Bacteriol. 39:430441.

26. Korn-Wendisch, F., and H. J. Kutzner. 1992. The family Streptomycetaceae, p. 921-995. In A. Balows, H. G. Trüper, M. Dworkin, W. Harder, and K.-H. Schleifer (ed.), The prokaryotes. Springer Verlag, Berlin.

27. Korn-Wendisch, F., and J. Schneider. 1992. Phage typing-a useful tool in actinomycete systematics. Gene 115:243-247.

28. Kothe, H. W., G. Vobis, R. M. Kroppenstedt, and A. Henssen. 1989. A taxonomic study of mycolateless wall chemotype IV actinomycetes. Syst. Appl. Microbiol. 12:61-69.

29. Kroppenstedt, R. M. 1982 . Separation of bacterial menaquinones by HPLC using reversed phase (RP18) and silver loaded ion exchanger as stationary phases. J. Liq. Chromatogr. 5:2359-2367.

30. Kroppenstedt, R. M. 1985 . Fatty acid analysis and menaquinone analysis of actinomycetes and related organisms. Soc. Appl. Bacteriol. Tech. Ser. 20:173-199.

31. Kroppenstedt, R. M. 1992. The genus Nocardiopsis, p. 1139-1156. In A. Balows, H. G. Trüper, M. Dworkin, W. Harder, and K.-H. Schleifer (ed.), The prokaryotes. Springer Verlag, Berlin.

32. Kroppenstedt, R. M., and M. Goodfellow. 1992. The family Thermomonosporaceae, p. 1085-1114. In A. Balows, H. G. Trüper, M. Dworkin, W. Harder, and K.-H. Schleifer (ed.), The prokaryotes. Springer Verlag, Berlin.

33. Kurup, V. P. 1984. Thermophilic actinomycetes: their role in hypersensitivity pneumonitis, p. 145-159. In L. Ortiz-Ortiz, L. F. Bojajil, and V. Yakoleff (ed.), Biological, biochemical, and biomedical aspects of actinomycetes. Academic Press, Inc. (London), Ltd., London.

34. Kutzner, H. J. 1981. The family Streptomycetaceae, p. 2028-2090. In M. P. Starr, H. Stolp, H. G. Trüper, A. Balows, and H. G. Schlegel (ed.), The prokaryotes. Springer Verlag, Berlin.

35. Kutzner, H. J., V. Böttiger, and R. D. Heitzer. 1978. The use of physiological criteria in the taxonomy of Streptomyces and Streptoverticillium, p. 25-29. In M. Mordarski, W. Kurylowicz, and J. Jeljaszewicz (ed.), Nocardia and Streptomyces. Proceedings of the International Symposium on Nocardia and Streptomyces, Warsaw, 1976. Gustav Fischer Verlag, Stuttgart, Germany.

36. Labeda, D. P., R. T. Testa, M. P. Lechevalier, and H. A. Lechevalier. 1984. Saccharothrix: a new genus of the Actinomycetales related to Nocardiopsis. Int. J. Syst. Bacteriol. 34:426-431.

37. Lacey, J. 1988. Actinomycetes as biodeteriogens and pollutants of the environment, p. 359-432. In M. Goodfellow, S. T. Williams, and M. Mordarski (ed.), Actinomycetes in biotechnology. Academic Press, San Diego, Calif.

38. Larsen, N., G. J. Olsen, B. L. Maidak, M. J. McCaughey, R. Overbeek, T. J. Macke, T. L. Marsh, and C. R. Woese. 1993. The Ribosomal Database Project. Nucleic Acids Res. 21:3021-3023.

39. Lechevalier, H. A., M. P. Lechevalier, and N. N. Gerber. 1971. Chemical composition as a criterion in the classification of actinomycetes. Adv. Appl. Microbiol. 14:47-72.

40. Lechevalier, M. P., D. de Bievre, and H. A. Lechevalier. 1977. Chemotaxonomy of aerobic actinomycetes: phospholipid composition. Biochem. Syst. Ecol. 5:249-260.

41. Lechevalier, M. P., and H. A. Lechevalier. 1970. Chemical composition as a criterion in the classification of aerobic actinomycetes. Int. J. Syst. Bacteriol. 20:435-444

42. Lechevalier, M. P., H. Prauser, D. P. Labeda, and J.-S. Ruan. 1986. Two new genera of nocardioform actinomycetes: Amycolata gen. nov. and Amycolatopsis gen. nov. Int. J. Syst. Bacteriol. 36:29-37.

43. Meyer, J. 1989. Genus Actinomadura Lechevalier and Lechevalier 1970a, $400^{\mathrm{AL}}$, p. 2511-2526. In S. T. Williams, M. E. Sharpe, and J. G. Holt (ed.), Bergey's manual of systematic bacteriology, vol. 4. Williams \& Wilkins, Baltimore.

44. Meyer, J. 1989. Genus Nocardiopsis Meyer 1976, 487 AL, p. 2562-2568. In S. T. Williams, M. E. Sharpe, and J. G. Holt (ed.), Bergey's manual of systematic bacteriology, vol. 4. Williams \& Wilkins, Baltimore.

45. Miller, L. T. 1982. A single derivatization method for bacterial fatty acid methyl esters including hydroxy acids. J. Clin. Microbiol. 16:584-586.

46. Minnikin, D. E., L. Alshamaony, and M. Goodfellow. 1975. Differentiation of Mycobacterium, Nocardia, and related taxa by thin layer chromatographic analysis of whole-cell methanolysates. J. Gen. Microbiol. 88:200-204.

47. Minnikin, D. E., A. G. O'Donnell, M. Goodfellow, G. Alderson, M. Athalye, A. Schaal, and J. H. Parlett. 1984. An integrated procedure for extraction of bacterial isoprenoid quinones and polar lipids. J. Microbiol. Methods 2:233-241.

48. Nonomura, H. 1989. Genus Microtetraspora Thiemann, Pagani and Beretta 1968 b, $296^{\text {AL }}$, p. 2531-2536. In S. T. Williams, M. E. Sharpe, and J. G. Holt (ed.), Bergey's manual of systematic bacteriology, vol. 4. Williams \& Wilkins, Baltimore.

49. Owen, R. J., and D. Pitcher. 1985. Current methods for estimating base composition and levels of DNA-DNA hybridization. Soc. Appl. Bacteriol. Tech. Ser. 20:67-93.

50. Rainey, F. A. R., M. Dorsch, H. W. Morgan, and E. Stackebrandt. 1992. 16S rDNA analysis of Spirochaeta thermophilia: its phylogenetic position and implications for the systematics of the order Spirochaetales. Syst. Appl. Microbiol. 15:197-202.

51. Rainey, F. A. R., and E. Stackebrandt. 1993. Phylogenetic analysis of the bacterial genus Thermobacteroides indicates an ancient origin of Thermobacteroides proteolyticus. Lett. Appl. Microbiol. 16:282-286.

52. Reasoner, D. J., and E. E. Geldreich. 1985. A new medium for the enumeration and subculture of bacteria from potable water. Appl. Environ. Microbiol. 49:1-7.

53. Schneider, J., F. Korn-Wendisch, and H. J. Kutzner. 1990. $\phi$ SC623, a temperate actinophage of Streptomyces coelicolor Müller, and its relatives $\phi S C 347$ and $\phi S C 681$. J. Gen. Microbiol. 136:767-772.

54. Schneider, J., D. Kramer, E. Grund, and H. J. Kutzner. 1989. Preliminary characterization of a group of actinophages of the thermophilic actinomycete genus Saccharomonospora. Intervirology 30:323-329.

55. Schneider, J., and H. J. Kutzner. 1989. Distribution of modules among the central regions of the genomes of several actinophages of Faenia and Saccharopolyspora. J. Gen. Microbiol. 135:1671-1678.

56. Schneider, J., and H. J. Kutzner. 1991. Description of eight new actinophage species of the Pseudonocardiaceae genus Saccharopolyspora. Syst. Appl. Microbiol. 14:72-78.

57. Shearer, M. C., P. M. Colman, R. M. Ferrin, L. J. Nisbet, and C. H. Nash. 1986. A new genus of the Actinomycetales: Kibdelosporangium aridum gen. nov., sp. nov. Int. J. Syst. Bacteriol. 36:47-54.

58. Shirling, E. B., and D. Gottlieb. 1966. Methods for characterization of Streptomyces species. Int. J. Syst. Bacteriol. 16:313-340.

59. Stackebrandt, E., R. M. Kroppenstedt, K.-D. Jahnke, C. Kemmerling, and H. Gürtler. 1994. Transfer of Streptosporangium viridogriseum (Okuda et al. 1966), Streptosporangium viridogriseum subsp. kofuense (Nonomura and Ohara 1969), and Streptosporangium albidum (Furumai et al. 1968) to Kutzneria gen. nov. as Kutzneria viridogrisea comb. nov., Kutzneria kofuensis comb. nov., and Kutzneria albida comb. nov., respectively, and emendation of 
the genus Streptosporangium. Int. J. Syst. Bacteriol. 44:265-269.

60. Stanek, J. L., and G. D. Roberts. 1974. Simplified approach to identification of aerobic actinomycetes by thin-layer chromatography. Appl. Microbiol. 28:226-231.

61. Takeuchi, M., T. Nishii, and A. Yokota. 1992. Taxonomic significance of arabinose in the family Pseudonocardiaceae. Actinomycetology 6:79-90.

62. Tamaoka, J., and K. Komagata. 1984. Determination of DNA base composition by reversed-phase high-performance liquid chromatography. FEMS Microbiol. Lett. 25:125-128.

63. Van den Bogart, H. G. G, G. Van den Ende, P. C. C. Van Loon, and L. J. L. D. Van Griensven. 1993. Mushroom worker's lung: serologic reactions to thermophilic actinomycetes present in the air of compost tunnels. Mycopathologia 122:21-28.

64. Warwick, S., T. Bowen, H. McVeigh, and T. M. Embley. 1994. A phylogenetic analysis of the family Pseudonocardiaceae and the genera Actinokineospora and Saccharothrix with 16S rRNA sequences and a proposal to combine the genera Amycolata and Pseudonocardia in an emended genus Pseudonocardia. Int. J. Syst. Bacteriol. 44:293-299.

65. Williams, S. T., and T. Cross. 1971. Actinomycetes. Methods Microbiol. 4:295-334.

66. Williams, S. T., M. Goodfellow, and G. Alderson. 1989. Genus Streptomyces Waksman and Henrici 1943, 339AL, p. 2452-2492. In S. T. Williams, M. E Sharpe, and J. G. Holt (ed.), Bergey's manual of systematic bacteriology, vol. 4. Williams \& Wilkins, Baltimore. 